\title{
Towards a Better Understanding of Relationship between Dubai Smart Government Characteristics and Organizational Performance
}

\author{
Obeid Alshamsi, Ali Ameen, Mohammed Nusari, Abuelhassan E. Abuelhassan, Amiya Bhumic
}

\begin{abstract}
The study aims at examining the influence of Dubai smart government characteristics on the governmental organization performance. Online survey was used to collect data for this study, the sample size was determined as 250 users of Dubai smart government services, who are users who got the services from five major strategic or government partners of smart government establishment: Dubai Police, RTA, DEWA, DHA, and Dubai Municipality. PLS (Partial Least Squares) SEM-VB (Structural Equation Modelling-Variance Based) was employed to assess the research model by utilizing the software SmartPLS 3.0. This paper adds to the existing literature of smart government characteristics (Information System Quality, Relationship with Public Agencies, Leadership, Accountability and Transparency, and Productivity) and governmental organization performance (Innovativeness, Efficiency, Collaboration, Communication, and Competition Intensity). The results of this study have the potential to give further insights into Dubai government to improve their organizations performance.
\end{abstract}

Keywords: Dubai smart government; organizations performance; Dubai; UAE.

\section{INTRODUCTION}

The information and communication technology (ICT) has been shaping the public and private around the globe [1]. In $21^{\text {st }}$ Century, the administration and governance idea has been transformed radically with adoption of innovative tools leading to enhancement in governmental services [2]. According to Jain, Harsh, \& Ichalkaranje (2015) [3], smart government is "the implementation of a set of business processes and underlying information technology capabilities that enable information to flow seamlessly across government agencies and programs to become intuitive in providing high quality citizen services across all government programs and activity domains". Puron-Cid (2015) [4] stated the smart government to be a subset of the smart city domain where an open dialogue between the citizens and city officials is enabled through an ICT platform.

In the UAE, Dubai is a highly advanced city in the field of applications of principles governance and the quality of government services, through the applications of excellence standards and performance measurement with transparency

Revised Manuscript Received on September 25, 2019

Obeid Alshamsi, Lincoln University College, Selangor, Malaysia

Ali Ameen, Lincoln University College, Selangor, Malaysia

Mohammed Nusari, Lincoln University College, Selangor, Malaysia

Abuelhassan E. Abuelhassan, Lincoln University College, Selangor, Malaysia

Amiya Bhumic, Lincoln University College, Selangor, Malaysia indicators [5]. Furthermore, smart Dubai Government Establishment is the technology arm of Smart Dubai. It is a city-wide initiative aiming at transforming Dubai into the smartest and happiest city of the world. It also aims at delivering world-class smart services and infrastructure for creation of happiness. HH Sheikh Mohammed Bin Rashid Al Maktoum, a visionary leader, UAE Vice President and Prime Minister and Ruler of Dubai equates technology to a building block towards an extraordinary quality of life; so technology is not its end goal [6].

Many literature studies have evaluated the impact of performance of public management by using different measures and data from multiple countries and industries [7-12]. In the context of Dubai, such studies are limited so as to evaluate the relationship between government or public management and smart government characteristics. Moreover, while above studies contribute to the understanding of the public management, they are inconclusive and limited in context of smart government platforms, through which public management can effectively be conducted.

Accordingly, this study serves to address and investigate such phenomenon in the context of Dubai Smart Government establishment. Furthermore, the study choose the performance of departments such as Dubai Police; Roads \& Transport Authority (RTA), Dubai Electricity and Water Authority (DEWA); Dubai Health Authority (DHA); and Dubai Municipality as they are awarded and highly related to directly provide services to all residents living in Dubai.

\section{LITERATURE REVIEW}

\section{A. Dubai Smart Government Characteristics (DSG)}

Smart governance includes "the aspects of political participation, services for citizens as well as the functioning of the administration" [13]. By reviewing all of above definitions, this paper defines smart government as the promotion of smart city initiatives to serve its users and public administration/management.

In order to derive the critical factors influencing smart government performance, several journal articles, as well as the researcher's opinions could be used. According to literature review, it is found that there are several studies that investigated the success or failure factors of e-government and smart government [14-20]. Accordingly, following factors can be established as the critical factors affecting Dubai smart government performance

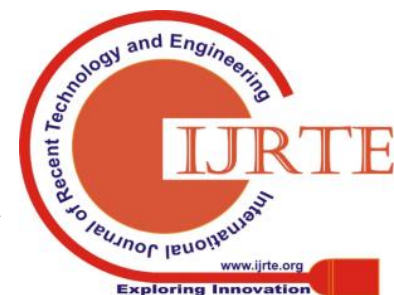




\section{[14, 17, 21-23].}

Development projects with integrated ICT can lead to change in the urban landscape of a city and offer numerous opportunities by which they can enhance the city's management and functioning [24]. According to Elkadi (2013) [20], information system factors directly impact the success or failure of e-government. As highlighted by DeLone \& McLean (2013) [19], information system success factors encompasses several aspects including the quality of information, system, and services.

Furthermore, though smart government initiatives are implemented in various governmental departments, such initiatives will not be successful as long as there is no strong relationship between governmental departments and people or beneficiaries. According to Al-Shafi \& Weerakkody (2010) [15], a poor relationship between people and public agencies has led to failure of some smart government initiatives in Qatar. Hence, it can be conceptualized that the government's strong trust relationship between people and public agencies or governmental departments positively affects the smart government performance.

Moreover, Leadership and management is the most crucial dimension affecting the successfulness of smart government initiatives. As part of the leadership's mandate, SDG is delivered with different tasks and powers that includes proposal of general strategy for running of the smart government; overseeing smart transformation processes at the level of government entities; reviewing government entities' plans and budgets related to smart transformation, IT, smart services and infrastructure; and proposing the legislation necessary for easing the smart transformation process [6]. Hence, it can be argued the degree to which those activities are led and manage will be determinants of Smart Dubai Government Establishment.

Moreover, in terms of governance, accountability is referred to answerability, blameworthiness, liability, and the expectation of account-giving, according to Dykstra (1939). Empirical studies indicate that the governance model of Smart Cities initiatives follow the same principles of the governance model preconized by e-government research area $[5,16,25$, 26] that is, being transparent and accountable.

Finally, economic development can be concerned as the critical external factor affecting the success of smart government initiatives. Economy is the major driver of smart city initiatives, and a city with a high degree of economic competitiveness is thought to have one of properties of a smart city, and thereby smart government [18]. Smart City Indicator survey in 2017 conducted by Johnson Controls amongst 150 smart city leaders found that economic development was one of the critical drivers of smart city initiatives [27]. Hence, it can be assumed that there is a direct association between successfulness of smart government and Dubai's economy performance. Consequently, the following hypotheses are proposed:

H1: Dubai smart government characteristics has a positive effect on governmental organizations performance.

\section{B. Governmental Organizations Performance (GOP)}

Organization performance as defined by Škrinjar, Bosilj-Vukšić, \& Indihar-Štemberger (2008) [28] comprises of actual organizational outcomes which are measured with respect to its expected output. Organizational performance measures make it possible for the organizations to emphasis more on the areas that require improvement by evaluating how well work is done with respect to cost, quality, and time. In view of this section, five major Dubai government departments (Dubai Police, RTA, DEWA, DHA, and Dubai Municipality) that are collaborating with Dubai smart government initiatives are considered. As a whole the key factors that can commonly be affecting their performance are reviewed as follows.

First, innovation in the context of public sectors can be defined as creative and novel changes made significantly to a government provision of goods and services, organizational methods and procedures, and communication between stakeholders [29]. As stated by Lopes (2017) [30], the principles behind the Smart Governance model can enable and potentiate significantly the creativity and innovation in the implementation of Smart Cities. Thus, it is clear that innovation is greatly linked with the concept of smart government and smart city [31]. To succeed the smart government implementation within each government departments, it should reflect a culture of creativity and innovation.

Second, the resources availability and efficient and effective utilization of resources including funds, staff, physical and intangible assets, and ICT infrastructure are critical for determining the performance of government departments. In other words, as the partners of Smart Dubai Government Establishment, each government department in Dubai has a duty and responsibility to be a part of smart government initiatives by implementing smart activities and solutions throughout their organizations.

Third, as it was noted in literature review, selected five governmental departments such as Dubai Police, RTA, DEWA, DHA, and Dubai Municipality are considered to be strategic partners of Smart Dubai Government establishment. Hence, their primary responsibility is to collaborate with Dubai Government initiatives by keeping strong relationship with the government. In other words, each government departments in Dubai ought to be in line with the vision, mission, goals, policies, and strategies of Smart Dubai Government establishment when carrying out their operations within their public agencies. Thus, the performance of each government department can be determined by the degree of strong trust relationship and collaboration that it has with the government.

Forth, public agencies have been using a number of methods to communicate with its beneficiaries such as words of mouth, printed materials and physical mails, e-mails, and websites etc. Nevertheless, the evaluation of ICTs and social media platforms such as Facebook, Twitter, Youtube, Google+, and Instagram, many government agencies at the federal, state and local levels have been increasingly adopting social media as an effective communication mechanism for representation, engagement and networking [32]. This is called for government departments and public agencies to "harness new 
technologies" to promote transparency and participatory public engagement [33].

Finally, Dubai government are implementing initiatives to improve the competitiveness amongst its government departments so that innovation, productivity, and championship across Smart Dubai Government Establishment can be enhanced. This competition amongst public agencies in Dubai is evident as it is promoted by conducting Smart Government Awards annually. The award is very interactive in nature and lets the public (both Emiratis and expatriates) vote for the best initiative of government entities [34]. Accordingly, it can rationally be argued that Dubai government departments' performance is influenced by their level of competitiveness in efforts to enhance Dubai's offerings and make government customers happy [21].

\section{Islamic Banking Performance (IBP)}

Organizational performance factor is one of the most significant parameters in the research related to management and perhaps the most significant guide to the overall performance of the organization. The organizational performance is a benchmark or an indicator for efficiency, effectiveness, and environmental obligation like productivity, time of cycle, reduction of waste, and compliance of rules. The large amount of definitions serve to view the performance of the organisations as a tool for achieving objectives. In short, the performance of the organisation is the most significant factor in evaluation of organisations, their activities, and the environments in which they work.

Despite all the facts and significant development of Islamic banking, the literature has still shown the lack of focus toward the efficiency of the Islamic banks. Since, it is found that most of the studies and researches in literature are generally focusing on the presentation of two types of banks; the Islamic financial intermediaries and the conventional banks with respect to the relationship between the features of the banks and their profitability. For instance, the study utilized bank level data in their researches and performed regression analysis in order to scrutinize the determinants associated with the performance of the Islamic Banks. Similarly, a study on the working of Islamic banking in Bangladesh in order to measure the efficiency of banks by using Banking Efficiency Model. In this research, researcher confirmed that the Islamic banks have potential to stay dynamic even in the conventional banking architecture where the profit and loss sharing methods of investments are of minimum dominance. Along with this, the researcher also found that the financial services and financial products in the Islamic the banking system possess different risk aspects therefore different prudential regulations have to be adopted. The current trend of automation and data exchange in manufacturing technologies. It includes cyber-physical systems, the Internet of things, cloud computing and cognitive computing [35].

\section{RESEARCH METHOD}

\section{A.Overview of the Proposed Conceptual Framework}

The conceptual model depicted in figure 1 , is theoretically represent how Dubai smart government can influence, Dubai governmental department performance. The model is developed and operationalized by reviewing the possible determinants of Dubai smart government characteristics, and Dubai governmental department performance.

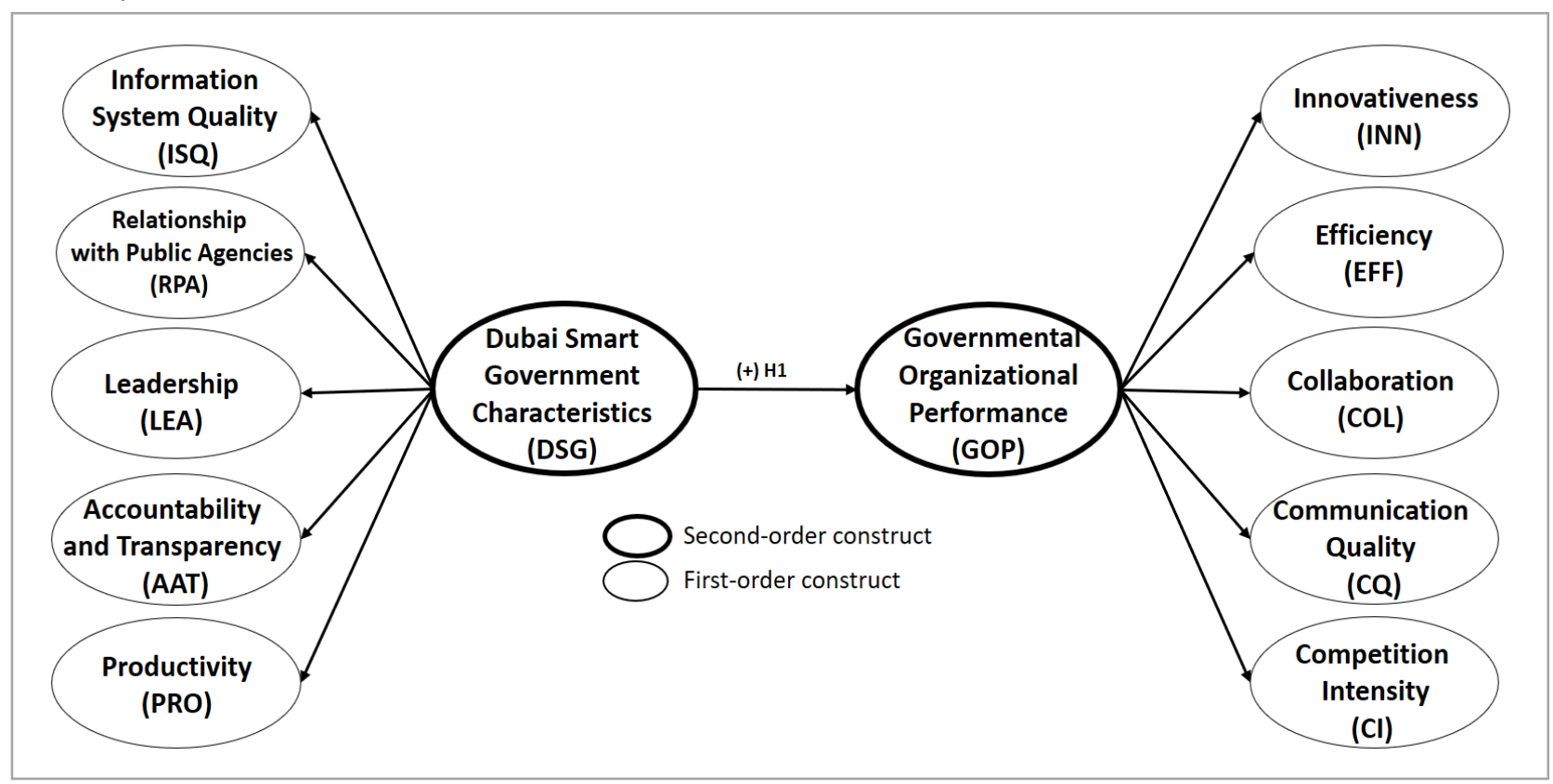

Fig. 1. The proposed conceptual framework select the beneficiaries of Dubai smart government services. The sample size was determined as 250 users of Dubai smart government services, who are users who got the services from

\section{B. Development of Instrument and Data collection}

Online survey was found as the most suitable tool as smart government are directly operated through ICT and artificial platforms where the internet tool is necessary for both service provider and users. Random sampling method was adopted to five major strategic or government partners of smart government establishment: Dubai Police, RTA, DEWA, DHA, and

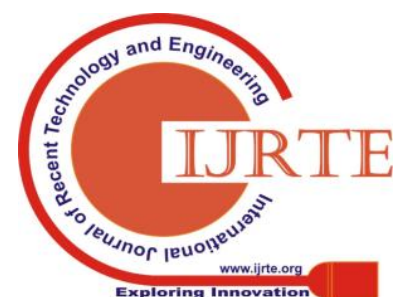


Dubai Municipality. Accordingly, with the permission of Dubai smart office, 400 email addresses of beneficiaries of Dubai smart government initiatives were randomly collected in line with the above criteria. The questionnaire, which was designed through Google Forms, was sent to selected email until the sample size was met. However, only 231 respondents were achieved a response rate of $92.4 \%$, which is considered to be a healthier survey response rate.

\section{Data AnAlysis AND Results}

PLS (Partial Least Squares) SEM-VB (Structural Equation Modelling-Variance Based) was employed to assess the research model by utilising the software SmartPLS 3.0 [36]. A two-phase analytical technique [37, 38] consisting of (i) measurement model analysis (reliability and validity) and (ii) structural model analysis (examining the conceptualised relationships) was employed after performing the descriptive assessment. This two-phase analytical technique consisting of a structural and a measurement model assessment is better than a single phase assessment [39]. While the model of measurement explains each parameter's measurement, the structural model describes the correlation between the parameters in this model [38]. Analysing Data through the second-generation multivariate data analysis technique which is SEM offers a simultaneous analysis which leads to more accurate estimates.

\section{A.Descriptive analysis}

Table 1 presents the mean and standard deviation of each variable in the current study. The respondents were asked to indicate their opinion in relation to transformational leadership and human capital based on a 7-point scale ranging from 1 (strongly disagree) to 7 (strongly agree). Competition Intensity score the highest with mean 4.361 out of 7.0 , with a standard deviation of 0.831 .

\section{B. Measurement Model Assessment}

Construct reliability as well as validity (comprising discriminant and convergent validity) were used to examine the measurement model. The particular alpha coefficients of Cronbach were tested to determine the reliability of every core parameter in the measurement model (construct reliability). The quantities of all the unique alpha coefficients of Cronbach in this research ranged from 0.818 to 0.874 , which went beyond the proposed value of 0.7 [40]. Moreover, for inspecting construct reliability, all the CR (composite reality) values ranged from 0.892 to 0.923 , which went beyond 0.7 [41]. Thus, as Table 1 shows, construct reliability have been fulfilled as Cronbach's CR and alpha were rather error-free for all the parameters.

Analysis of indicator reliability was conducted by utilising factor loadings. When the related indicators are very similar, this is reflected in the construct and signified by the construct's high loadings [38]. As per Hair et al. (2010) [39], the exceeding of values beyond 0.70 suggests substantial factor loadings. Table 1 displays that all articles in this research had factor loadings greater than the suggested value. AVE (average variance extracted) was employed in this study to analyse convergent validity, which represents the degree to which a measure is correlated positively with the same construct's other measures. All the AVE values ranged from 0.734 and 0.799 , which went beyond the proposed value of 0.50 [39]. Thus, all constructs have complied with the convergent validity acceptably, as shown in Table 1 .

Table 1: Mean, standard deviation, loading, cronbach's Alpha, CR and AVE

\begin{tabular}{|c|c|c|c|c|c|c|c|}
\hline Constructs & Item & $\begin{array}{c}\text { Loading } \\
(>0.7)\end{array}$ & $\mathrm{M}$ & SD & $\begin{array}{c}\alpha \\
(>0.7)\end{array}$ & $\begin{array}{c}\mathrm{CR} \\
(>0.7)\end{array}$ & $\begin{array}{c}\text { AVE } \\
(>0.5)\end{array}$ \\
\hline $\begin{array}{c}\text { Information } \\
\text { System Quality } \\
\text { (ISQ) }\end{array}$ & $\begin{array}{l}\text { ISQ1 } \\
\text { ISQ2 } \\
\text { ISQ3 } \\
\end{array}$ & $\begin{array}{l}0.851 \\
0.880 \\
0.853\end{array}$ & $\begin{array}{c}4.16 \\
0\end{array}$ & $\begin{array}{c}0.82 \\
7\end{array}$ & 0.827 & 0.896 & 0.742 \\
\hline $\begin{array}{l}\text { Relationship } \\
\text { with Public } \\
\text { Agencies } \\
\text { (RPA) } \\
\end{array}$ & $\begin{array}{l}\text { RPA1 } \\
\text { RPA2 } \\
\text { RPA3 }\end{array}$ & $\begin{array}{l}0.819 \\
0.895 \\
0.855\end{array}$ & $\begin{array}{c}4.23 \\
9\end{array}$ & $\begin{array}{c}0.84 \\
7\end{array}$ & 0.818 & 0.892 & 0.734 \\
\hline $\begin{array}{l}\text { Leadership } \\
\text { (LEA) }\end{array}$ & $\begin{array}{l}\text { LEA1 } \\
\text { LEA2 } \\
\text { LEA3 } \\
\end{array}$ & $\begin{array}{l}0.844 \\
0.877 \\
0.869\end{array}$ & $\begin{array}{c}4.21 \\
8\end{array}$ & $\begin{array}{c}0.83 \\
4\end{array}$ & 0.829 & 0.898 & 0.745 \\
\hline $\begin{array}{l}\text { Accountability } \\
\text { and } \\
\text { Transparency } \\
\text { (AAT) }\end{array}$ & $\begin{array}{l}\text { AAT1 } \\
\text { AAT2 } \\
\text { AAT3 }\end{array}$ & $\begin{array}{l}0.833 \\
0.897 \\
0.861\end{array}$ & $\begin{array}{c}4.17 \\
9\end{array}$ & $\begin{array}{c}0.84 \\
2\end{array}$ & 0.829 & 0.898 & 0.746 \\
\hline $\begin{array}{l}\text { Productivity } \\
\text { (PRO) }\end{array}$ & $\begin{array}{l}\text { PRO1 } \\
\text { PRO2 } \\
\text { PRO3 } \\
\end{array}$ & $\begin{array}{l}0.854 \\
0.864 \\
0.867\end{array}$ & $\begin{array}{c}4.16 \\
9\end{array}$ & $\begin{array}{c}0.80 \\
4\end{array}$ & 0.826 & 0.896 & 0.742 \\
\hline $\begin{array}{c}\text { Innovativeness } \\
\text { (INN) }\end{array}$ & $\begin{array}{l}\text { INN1 } \\
\text { INN2 } \\
\text { INN3 } \\
\end{array}$ & $\begin{array}{l}0.878 \\
0.903 \\
0.887 \\
\end{array}$ & $\begin{array}{c}4.20 \\
4\end{array}$ & $\begin{array}{c}0.87 \\
1\end{array}$ & 0.868 & 0.919 & 0.791 \\
\hline
\end{tabular}


International Journal of Recent Technology and Engineering (IJRTE) ISSN: 2277-3878, Volume-8 Issue-2S10, September 2019

\begin{tabular}{|c|c|c|c|c|c|c|c|}
\hline $\begin{array}{l}\text { Efficiency } \\
\text { (EFF) }\end{array}$ & $\begin{array}{l}\text { EFF1 } \\
\text { EFF2 } \\
\text { EFF3 }\end{array}$ & $\begin{array}{l}0.856 \\
0.901 \\
0.875\end{array}$ & $\begin{array}{c}4.27 \\
4\end{array}$ & $\begin{array}{c}0.80 \\
3\end{array}$ & 0.850 & 0.909 & 0.770 \\
\hline $\begin{array}{l}\text { Collaboration } \\
\quad(\mathrm{COL})\end{array}$ & $\begin{array}{l}\text { COL1 } \\
\text { COL2 } \\
\text { COLE } \\
\end{array}$ & $\begin{array}{l}0.866 \\
0.866 \\
0.880 \\
\end{array}$ & $\begin{array}{c}4.29 \\
0\end{array}$ & $\begin{array}{c}0.80 \\
2\end{array}$ & 0.840 & 0.904 & 0.758 \\
\hline $\begin{array}{c}\text { Communication } \\
\text { Quality } \\
\text { (CQ) }\end{array}$ & $\begin{array}{l}\text { CQ1 } \\
\text { CQ2 } \\
\text { CQ3 }\end{array}$ & $\begin{array}{l}0.876 \\
0.884 \\
0.893\end{array}$ & $\begin{array}{c}4.26 \\
8\end{array}$ & $\begin{array}{c}0.85 \\
1\end{array}$ & 0.861 & 0.915 & 0.783 \\
\hline $\begin{array}{l}\text { Competition } \\
\text { Intensity } \\
\text { (CI) }\end{array}$ & $\begin{array}{l}\text { CI1 } \\
\text { CI2 } \\
\text { CI3 }\end{array}$ & $\begin{array}{l}0.897 \\
0.913 \\
0.871\end{array}$ & $\begin{array}{c}4.36 \\
1\end{array}$ & $\begin{array}{c}0.81 \\
3\end{array}$ & 0.874 & 0.923 & 0.799 \\
\hline
\end{tabular}

Note: $\mathrm{M}=$ Mean; $\mathrm{SD}=$ Standard Deviation, $\alpha=$ Cronbach's alpha; $\mathrm{CR}=$ Composite Reliability, AVE = Average Variance Extracted.

Key: ISQ: information system quality; RPA: relationship with public agencies; LED: leadership; AAT: accountability and transparency; PRO: productivity; INN: innovativeness; EFF: efficiency; COL: collaboration; CQ: communication quality; CI: competition intensity.

The degree to which the articles distinguish among concepts or measure different constructs is demonstrated by discriminant validity. Fornell-Larcker was employed to analyse the measurement model's discriminant validity. Table 2 shows the outcomes for discriminant validity by employing the Fornell-Larcker condition. It was discovered that the AVEs' square root on the diagonals (displayed in bold) is bigger than the correlations among constructs (corresponding row as well as column values), suggesting a strong association between the concepts and their respective markers in comparison to the other concepts in the model [42, 43]. According to Hair et al. (2017) [38], this indicates good discriminant validity. Furthermore, the exogenous constructs have a correlation of less than 0.85 [44]. Therefore, all constructs had their discriminant validity fulfilled satisfactorily.

Table 2: Results of discriminant validity by Fornell-Larcker criterion

\begin{tabular}{l|cccccccccc}
\hline & $A A T$ & $C I$ & $C O L$ & $C Q$ & $E F F$ & $I N N$ & $I S Q$ & $L E A$ & $P R O$ & $R P A$ \\
\hline AAT & $\mathbf{0 . 8 6 4}$ & & & & & & & & & \\
CI & 0.378 & $\mathbf{0 . 8 9 4}$ & & & & & & & & \\
COL & 0.397 & 0.765 & $\mathbf{0 . 8 7 1}$ & & & & & & & \\
CQ & 0.379 & 0.818 & 0.759 & $\mathbf{0 . 8 8 5}$ & & & & & \\
EFF & 0.426 & 0.790 & 0.749 & 0.801 & $\mathbf{0 . 8 7 7}$ & & & & \\
INN & 0.400 & 0.768 & 0.789 & 0.807 & 0.818 & $\mathbf{0 . 8 8 9}$ & & & \\
ISQ & 0.758 & 0.295 & 0.303 & 0.278 & 0.327 & 0.291 & $\mathbf{0 . 8 6 2}$ & & & \\
LEA & 0.787 & 0.276 & 0.288 & 0.259 & 0.311 & 0.277 & 0.750 & $\mathbf{0 . 8 6 3}$ & & \\
PRO & 0.756 & 0.342 & 0.393 & 0.327 & 0.382 & 0.340 & 0.656 & 0.696 & $\mathbf{0 . 8 6 2}$ & \\
RPA & 0.783 & 0.321 & 0.320 & 0.333 & 0.365 & 0.351 & 0.774 & 0.749 & 0.720 & $\mathbf{0 . 8 5 7}$ \\
\hline
\end{tabular}

Note: Diagonals represent the square root of the average variance extracted while the other entries represent the correlations.

Key: ISQ: information system quality; RPA: relationship with public agencies; LED: leadership; AAT: accountability and transparency; PRO: productivity; INN: innovativeness; EFF: efficiency; COL: collaboration; CQ: communication quality ;CI

\section{Structural Model Assessment} :competition intensity.

The structural model can be tested by computing beta $(\beta)$, procedure with a resample of 5,000 [38]. $\mathrm{R}^{2}$, and the corresponding $\mathrm{t}$-values via a bootstrapping 


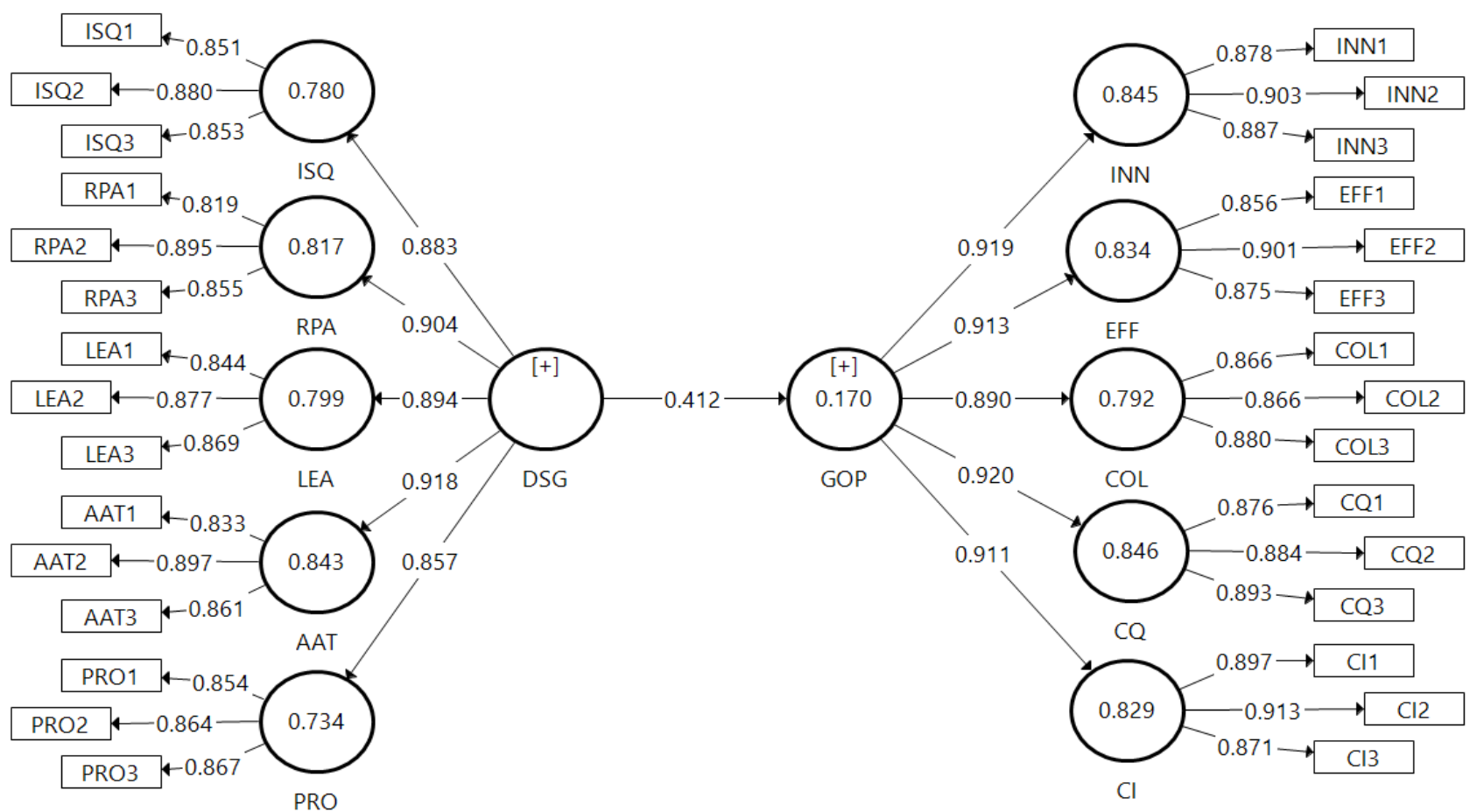

Key: DSG: Dubai smart government characteristics; ISQ: information system quality; RPA: relationship with public agencies; LED: leadership; AAT: accountability and transparency; PRO: productivity; GOP: governmental organizations performance; INN: innovativeness; EFF: efficiency; COL: collaboration; CQ: communication quality; CI: competition intensity

Fig 2: PLS algorithm results

Figure 2 and Table 3 depict the structural model assessment, showing the results of the hypothesis tests. Dubai smart government characteristics positively influence governmental organizations performance. Hence, $\mathrm{H} 1$ is accepted with $(\beta=0.412, \mathrm{t}=4.063, \mathrm{p}<0.001)$. Seventeen

percent of the variance in governmental organizations performance is explained by Dubai smart government characteristics. The values of $\mathrm{R}^{2}$ have an acceptable level of explanatory power, indicating a substantial model [43, 45].

Table 3: Structural path analysis result

\begin{tabular}{cccccccc}
\hline \hline Hypothesis & Relationship & $\begin{array}{c}\text { Std } \\
\text { Beta }\end{array}$ & $\begin{array}{c}\text { Std } \\
\text { Error }\end{array}$ & t-value & p-value & Decision & $\mathrm{R}^{2}$ \\
\hline H1 & $\begin{array}{c}\text { DSG } \rightarrow \\
\text { GOP }\end{array}$ & 0.412 & 0.101 & 4.063 & 0.000 & Supported & 0.1 \\
7
\end{tabular}

Key: DSG: Dubai smart government characteristics; GOP: governmental organizations performance..

\section{DISCUSSION}

The main objective of the current study is to address the impact of Dubai smart government characteristics on the governmental organization performance. The hypothesis of this study was supported with $(\beta=0.412, \mathrm{t}=4.063$, $\mathrm{p}$ $<0.001)$. This result can be explained by the fact that the more quality of Dubai smart government programs system is high and reliable, Dubai government effectively coordinates and collaborates its smart government establishment with its all public agencies, The leadership Smart Dubai Government Establishment is visionary and effective, Smart Dubai Government Establishment facilitates access to information, economic activity and conduct of business, Smart Dubai Government Establishment improves the productivity in the state; the more government department's innovation is more competitive than other public departments, Resources are effectively and efficiently allocated and monitored within the department, government department is collaborating with Smart Dubai Government establishment effectively, government department is effectively communicated with beneficiaries, and government department is more competitive than other departments in providing public services. At the end, H1 was supported the Dubai smart government characteristics has a positive direct impact on the governmental organization performance.

\section{IMPLICATIONS, LIMITATIONS AND FUTURE DIRECTIONS}

One of the implications is that, Dubai governmental departments such as Dubai Police, RTA, DEWA, DHA, and Dubai Municipality will also benefit from the findings of this study as it investigate the impact of Dubai Smart Government establishment on the performance of such department. Accordingly, Dubai Smart Government establishment can effectively enhance its strategies and polices to improve its contribution on achieving the objectives of Dubai government departments such as Dubai Police, RTA, DEWA, DHA, and Dubai Municipality. One of the limitations of this study is that the data gathered was cross-sectional rather than

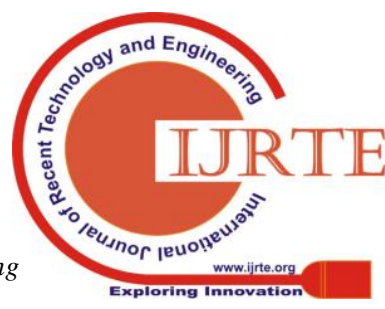


longitudinal in nature. The longitudinal method might improve the understanding of the associations and the causality between variables. Future research should be conducted to investigate the relationship between variables by conducting cross-cultural studies as recommended by previous studies.

Moreover, the findings of this study is important to the researchers and business firms in private sector. Since no empirical study investigating the significant relationship between smart government initiatives and governmental organization performance can be seen in Middle East and other parts of the world, so that this research will develop the initial platform continue in researching: the impact of the performance of Dubai governmental departments on smart government functioning and thereby; the significant determinants of a smart government program. Business firms in private sector, on the other hand, will be able to identify the possible opportunities and threats arising as a result of operating Dubai Smart Government establishment as they have also been customers that are receiving the services from Dubai Smart Government initiatives [56].

Furthermore, the study concentrates on the significant determinants of Dubai Smart Government establishment with the purpose of developing a model for the performance of smart government. The study, on the other hand, is limited to Dubai city as it is the first city in the Middle East in launching smart government initiatives. Therefore, findings of this study may not applicable in the context of other cities in world that implemented smart government initiatives. The reason for this

\section{APPENDIX}

Appendix A

Instrument for varibles

\begin{tabular}{|c|c|c|}
\hline Varible & Measure & Source \\
\hline $\begin{array}{c}\text { Information } \\
\text { System Quality } \\
\text { (ISQ) }\end{array}$ & $\begin{array}{l}\text { ISQ1: The quality of Dubai smart government programmes system is high and } \\
\text { reliable. } \\
\text { ISQ2: The quality of information provided by Dubai smart government programmes } \\
\text { is high. } \\
\text { ISQ3: The quality of the service and support that system users receive from Dubai } \\
\text { smart government programmes is high. }\end{array}$ & $\begin{array}{l}{[19,} \\
20]\end{array}$ \\
\hline $\begin{array}{l}\text { Relationship } \\
\text { with Public } \\
\text { Agencies } \\
\text { (RPA) }\end{array}$ & $\begin{array}{l}\text { RPA1: Dubai smart government initiatives have a strong trust relationship with } \\
\text { people } \\
\text { RPA2: Dubai smart government initiatives have a strong trust relationship with } \\
\text { public agencies } \\
\text { RPA3: Dubai government effectively coordinates and collaborates its smart } \\
\text { government establishment with its all public agencies }\end{array}$ & [15] \\
\hline $\begin{array}{l}\text { Leadership } \\
\quad \text { (LED) }\end{array}$ & $\begin{array}{l}\text { LE1: The leadership Smart Dubai Government Establishment is visionary and } \\
\text { effective. } \\
\text { LE2: The vision and mission of Smart Dubai Government Establishment are well } \\
\text { communicated over the governmental departments. } \\
\text { LE3: The changes in the external and internal environment is promptly and } \\
\text { effectively responded. }\end{array}$ & [30] \\
\hline $\begin{array}{c}\text { Accountability } \\
\text { and } \\
\text { Transparency } \\
\text { (AAT) }\end{array}$ & $\begin{array}{l}\text { AAT1: Dubai smart government's decision-making and operations are more } \\
\text { transparent. } \\
\text { AAT2: Smart Dubai Government Establishment facilitates access to information, } \\
\text { economic activity and conduct of business. } \\
\text { AAT3: Smart Dubai Government Establishment increase accountability and reduce } \\
\text { corruption. }\end{array}$ & {$[5,25]$} \\
\hline
\end{tabular}

might be the countries' differences in political and economic dimensions, and demographic variables, which can affect the ways of implementing smart government initiatives, and how people perceive such initiatives. Nonetheless, this study is able to provide such cities with general understandings on how smart government platform affects the level of governmental organization performance.

\section{CONCluSION}

The main objective of this study was to examine the impact of Dubai smart government characteristics on the governmental organization performance. The proposed model provides a better understanding of characteristics of Dubai smart government such as (Information System Quality, Relationship with Public Agencies, Leadership, Accountability and Transparency, and Productivity) on the governmental organizations performance in term of (Innovativeness, Efficiency, Collaboration, Communication, and Competition Intensity). The results from the descriptive analysis showed that there is a positive direct impact of the DSG on the GOP. Dubai government needs to pay more attention to the smart government characteristics to improve the performance of its governmental organizations. The implications of this present study from the perspective of academics and practitioners have been discussed, along with the limitations and some directions for future research. 


\begin{tabular}{|c|c|c|}
\hline $\begin{array}{l}\text { Productivity } \\
\text { (PRO) }\end{array}$ & $\begin{array}{l}\text { PRO1: Dubai's economy is smart and features global competitiveness. } \\
\text { PRO2: Smart Dubai Government Establishment improves the productivity in the } \\
\text { state. } \\
\text { PRO3: There is a direct association between Dubai's smart economy and smart } \\
\text { government concepts. }\end{array}$ & {$[18]$} \\
\hline $\begin{array}{l}\text { Innovativeness } \\
\text { (INN) }\end{array}$ & $\begin{array}{l}\text { INN1: This government department is showing a culture of innovation. } \\
\text { INN2: The creativity of the public service given by the government department you } \\
\text { work in or receive services is high. } \\
\text { INN3: This government department's innovation is more competitive than other } \\
\text { public departments. }\end{array}$ & $\begin{array}{l}{[29,} \\
30]\end{array}$ \\
\hline $\begin{array}{l}\text { Efficiency } \\
\text { (EFF) }\end{array}$ & $\begin{array}{l}\text { EFF1: The resources required for the department's operations are adequate. } \\
\text { EFF2: Resources are effectively and efficiently allocated and monitored within the } \\
\text { department. } \\
\text { EFF3: Wastage in the utilization of a resource within the department is minimal. }\end{array}$ & [18] \\
\hline $\begin{array}{c}\text { Collaboration } \\
\text { (COL) }\end{array}$ & $\begin{array}{l}\text { COL1: This government department is collaborating with Smart Dubai Government } \\
\text { establishment effectively. } \\
\text { COL2: This government department is effectively collaborating with other } \\
\text { departments where appropriate. } \\
\text { COL3: The aims and values of the department are based on the principles of Smart } \\
\text { Dubai Government establishment. }\end{array}$ & [15] \\
\hline $\begin{array}{l}\text { Communication } \\
\text { Quality } \\
\text { (CQ) }\end{array}$ & $\begin{array}{l}\text { CQ1: This government department is effectively communicated with beneficiaries. } \\
\text { CQ2: The barriers to effective communication with the beneficiaries within this } \\
\text { government department are effectively managed. } \\
\text { CQ3: The most preferred communication methods currently being used by the } \\
\text { department is social media and website. }\end{array}$ & $\begin{array}{l}{[32,} \\
33]\end{array}$ \\
\hline $\begin{array}{l}\text { Competition } \\
\text { Intensity } \\
\quad \text { (CI) }\end{array}$ & $\begin{array}{l}\text { CI1: This government department is more competitive than other departments in } \\
\text { providing public services. } \\
\text { CI2: Innovation and productivity of the department are superior to other government } \\
\text { departments. } \\
\text { CI3: This government department was announced or is likely to be announced for } \\
\text { any Smart Government Awards. }\end{array}$ & [14] \\
\hline
\end{tabular}

\section{REFERENCES}

1. A. M. Mutahar, N. M. Daud, R. Thurasamy, O. Isaac \& R. Abdulsalam (2018). The Mediating of Perceived Usefulness and Perceived Ease of Use : The Case of Mobile Banking in Yemen. International Journal of Technology Diffusion, 9(2), pp. 21-40.

2. A. H. Aldholay, O. Isaac, Z. Abdullah \& T. Ramayah (2018). The role of transformational leadership as a mediating variable in DeLone and McLean information system success model: The context of online learning usage in Yemen. Telematics and Informatics, 35(5), pp. 1421-1437.

3. L. Jain, A. Harsh \& N. Ichalkaranje, (2015). Transforming e-Government to Smart Government: A South Australian Perspective. In Intelligent Computing, Communication and Devices pp. 9-16.

4. G. Puron-Cid (2015). Smart City: How to Create Public and Economic Value with High Technology in Urban Space. International Journal of E-Planning Research, 4, pp. 74-76.

5. S. Alawadhi, \& H. Scholl, (2013). Aspirations and Realizations: The Smart City of Seattle. In Proceedings of the Annual Hawaii International Conference on System Sciences pp. 1695-1703.

6. Smart Dubai Government Establishment. (2017). About Dubai Smart Government.

7. R. Andrews \& S.Van de Walle (2013). New Public Management and Citizens' Perceptions of Local Service Efficiency, Responsiveness, Equity and Effectiveness. Public Management Review Vol. 15.

8. E. Gerrish, (2015). The Impact of Performance Management on Performance in Public Organizations: A Meta-Analysis. Public Administration Review Vol. 76.

9. A. Grosso \& G. Van Ryzin (2012). Public Management Reform and Citizen Perceptions of the UK Health System. International Review of Administrative Sciences Vol. 78.

10. U. Hvidman \& S. Andersen (2013). The Impact of Performance Management in Public and Private Organizations. Journal of Public Administration Research and Theory Vol. 24.

11. P. Koning \& C. Heinrich (2013). Cream-Skimming, Parking and Other Intended and Unintended Effects of High-Powered, Performance-Based Contracts. Journal of Policy Analysis and Management Vol. 32.
12. S. Woolhandler, D. Ariely \& D. U. Himmelstein (2012). Why pay for performance may be incompatible with quality improvement. BMJ, 345 .

13. R. Giffinger, C. Fertner, H. Kramar, R. Kalasek, N. Milanović \& Meijers, E. (2007). Smart cities - Ranking of European medium-sized cities. Vienna University of Technology.

14. F. Al-Obthani, A. Ameen, M. Nusari, \& I. Alrajawy (2018). Proposing SMART-Government Model: Theoretical Framework. 1st International Journal of Management and Human Science (IJMHS) Vol. 2.

15. S. Al-Shafi \& V. Weerakkody, (2010). Factors affecting e-government adoption in the state of Qatar. In European and Mediterranean Conference on Information Systems 2010 (EMCIS2010) (pp. 1-23). Abu Dhabi, UAE.

16. S. Alawadhi \& H. Scholl (2016). Smart Governance: A Cross-Case Analysis of Smart City Initiatives. In 49th Hawaii International Conference on System Sciences (HICSS) pp. 2953-2963. Koloa, HI, USA.

17. R. AlShamsi, A. Ameen \& A. A.-. Shibami (2017). The Influence of Smart Government on Happiness: Proposing Framework. In 1st International Conference on Management and Human Science (ICMHS 2017) (p. 2017). Kuala Lumpur, Malaysia.

18. H. Chourabi, T. Nam, S.Walker, J. R. Gil-Garcia, S. Mellouli, K. Nahon, H. Scholl, (2012). Understanding Smart Cities: An Integrative Framework. 45th Hawaii International Conference on System Sciences.

19. W. DeLone \& E. R. McLean, (2013). Information Systems Success: The Quest for the Independent Variables AU - Petter, Stacie. Journal of Management Information Systems, 29(4), pp. 7-62.

20. H. Elkadi (2013). Success and failure factors for e-government projects: A case from Egypt. Egyptian Informatics Journal, 14(2), pp. $165-173$.

21. D. Al-Ali \& A. Ameen, (2018). The Influence of System Quality and 
Information Quality on User Satisfaction: The Case of Smart Government in UAE. In 2nd International Conference on Management and Human Science (ICMHS 2018), 27-28 November 2018, Kuala Lumpur, Malaysia Vol. 7, pp. 58-74.

22. K. Al-Ali, A. Ameen \& I. Alrajawy (2018). The Role of SMART Government on Enhancing Pubic Service Quality: Performance Quality Is a Mediator Factor. In International Conference on Recent Trends in Business and Entrepreneurial Ventures (ICRTBEV2018) (p. 23).

23. S. Albreki \& A. Ameen, (2017). The Influence of Quality of Knowledge Management on the Smart Government: Literature Review. In 1st International Conference on Management and Human Science (ICMHS2017) (p. 2017). Kuala Lumpur, Malaysia.

24. N. Odendaal (2003). Information and communication technology and local governance: Understanding the difference between cities in developed and emerging economies. Computers, Environment and Urban Systems Vol. 27.

25. M. do R. M. Bernardo (2017). Smart City Governance: From E-Government to Smart Governance. In Handbook of Research on Entrepreneurial Development and Innovation within Smart Cities pp. 290-326.

26. T. Nam \& T. Pardo (2011). Conceptualizing smart city with dimensions of technology, people, and institutions. ACM International Conference Proceeding Series.

27. Smart city. (2018). Driving Forces That Stimulate The Growth Of Smart Cities.

28. R. Škrinjar, V. Bosilj-Vukšić \& M. Indihar-Štemberger, (2008). The impact of business process orientation on financial and non-financial performance. Business Process Management Journal, 14(5), pp. $738-754$.

29. P. H. Bloch (2011). Product Design and Marketing: Reflections after Fifteen Years. Journal of Product Innovation Management, 28(3), pp. $378-380$.

30. N. Lopes (2017). Smart governance: A key factor for smart cities implementation. In IEEE International Conference on Smart Grid and Smart Cities (ICSGSC) (pp. 277-282).

31. M. Batey, M. Burd, D. Hughes, I. Moonesar \& F. Salem (2018) Creativity and Innovation in the Dubai Government: Exploring Individual, Team and Organisational Factors That Underlie Creativity \& Innovation in the Dubai Government.

32. I. Mergel (2013). Social media adoption and resulting tactics in the U.S. federal government. Government Information Quarterly, 30(2), pp. 123-130.

33. J. H. Liu, W.Shi, O. A. Elrahman, (Sam), Ban, X. (Jeff), \& Reilly, J. M. (2016). Understanding social media program usage in public transit agencies. International Journal of Transportation Science and Technology, 5(2), pp. 83-92.

34. Khaleej Times. (2016). Over 14 Dubai government entities bag "smart" awards. 